DOI: https://doi.org/10.47405/mjssh.v6i2.666

\begin{tabular}{|c|c|}
\hline 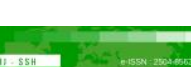 & Malaysian Journal of Social Sciences and Humanities (MJSSH) \\
\hline Malaysian Journal of & Volume 6, Issue 2, February 2021 \\
\hline (MJ-ssH) & e-ISSN : 2504-8562 \\
\hline & $\begin{array}{l}\text { Journal home page: } \\
\text { www.msocialsciences.com }\end{array}$ \\
\hline
\end{tabular}

\title{
Pelaksanaan Pedagogi Inklusif bagi Murid Berkeperluan Khas Masalah Pembelajaran
}

\author{
Hazlin Binti Haris' ${ }^{1}$ Khairul Farhah Khairuddin'1 \\ ${ }^{1}$ Fakulti Pendidikan, Universiti Kebangsaan Malaysia (UKM) \\ Correspondence: Khairul Farhah Khairuddin (kfk@ukm.edu.my)
}

\begin{abstract}
Abstrak
Pedagogi inklusif merupakan amalan pengajaran yang melibatkan penyertaan semua murid tanpa mendiskriminasikan berdasarkan latar belakang sosioekonomi, tahap kognitif, gender, budaya dan gaya pembelajaran yang berbeza. Kajian ini bertujuan untuk meneroka pelaksanaan pedagogi inklusif dan meninjau kesan pedagogi inklusif kepada perkembangan sosial murid berkeperluan khas masalah pembelajaran. Reka bentuk kajian ini adalah kajian kes yang menggunakan kaedah kualitatif. Tiga orang guru aliran perdana ditemu bual dan data dianalisis menggunakan kaedah analisis tema berpandukan model pengajaran Le Francois. Dapatan kajian menunjukkan bahawa terdapat kepelbagaian kaedah yang digunakan iaitu pembelajaran secara koperatif, pembelajaran secara aktif, pembelajaran Non-Directive Teaching Model, kaedah bercerita dan kaedah pengajaran bersama (coteaching). Antara kelebihan amalan pedagogi inklusif adalah peningkatan kemahiran sosial murid dari aspek keyakinan diri, bekerjasama, penyertaan bersama, perkongsian idea, dan berdikari. Kepentingan kajian ini telah memberi peluang kepada murid berkeperluan khas untuk mendapatkan pengalaman pembelajaran menerusi akomodasi persekitaran yang menyokong perkembangan kemahiran sosial murid berdasarkan peluang pembelajaran yang disediakan oleh guru.
\end{abstract}

Kata kunci: murid berkeperluan khas, pedagogi inklusif, pendidikan khas, program pendidikan inklusif

\section{Implementation of Inclusive Pedagogy for Students Special Needs Learning Disabilities}

\begin{abstract}
Inclusive pedagogy is a teaching practice that involves the participation of all students without discrimination based on different socioeconomic backgrounds, cognitive levels, gender and culture. This study aims to explore the implementation of inclusive pedagogy and examine the impact of inclusive pedagogy on the social development of students with special needs learning problems. The design of this study is a case study using qualitative methods. Three mainstream teachers were interviewed and the data were analyzed using a theme analysis method based on Le Francois teaching model. The findings show that there are a variety of methods used, namely cooperative learning, active learning, Non-Directive Teaching Model learning, storytelling methods and co-teaching methods. Among the advantages of inclusive pedagogical practice are the improvement of students' social skills in terms of self-confidence, cooperation, joint participation, idea sharing, and independence. The importance of this study has provided opportunities for students with special needs to gain learning
\end{abstract}


experience through environmental accommodation that supports the development of students' social skills based on learning opportunities provided by teachers.

Keywords: pupils with special needs, inclusive pedagogy, special education, inclusive education program

\section{Pengenalan}

'Pendidikan Untuk Semua' bukan hanya sekadar slogan atau ideal semata-mata tetapi realiti yang perlu kita laksanakan. Di peringkat pendidikan antarabangsa, slogan ini telah mengutamakan persekitaran pembelajaran tanpa halangan. Ini membawa maksud semua murid termasuk MBK (murid berkeperluan khas) dan MBT (murid berisiko tinggi) diberikan hak untuk belajar dan bermain seperti murid arus perdana yang lain. Di Malaysia terdapat beberapa dasar yang turut bersama-sama menyokong pelaksanaan Program Pendidikan Inklusif yang dijalankan antaranya ialah Akta Orang Kurang Upaya 2008, Peraturan Pendidikan Khas 2013, Pelan Pembangunan Pendidikan Malaysia (PPPM) (20132025). Program Pendidikan Inklusif adalah suatu program pendidikan bagi murid berkeperluan pendidikan khas yang dihadiri oleh murid berkeperluan pendidikan khas bersama-sama dengan murid lain dalam kelas yang sama di sekolah kerajaan atau sekolah bantuan kerajaan.

Program Pendidikan Inklusif terbahagi kepada dua pendekatan iaitu inklusif penuh dan inklusif separa. Terdapat perbezaan di antara kedua-dua inklusif tersebut iaitu dari segi tempat pembelajaran dan tenaga pengajarnya (Noor Aini, 2014). MBK inklusif penuh didaftarkan dalam APDM (Aplikasi Pangkalan Data Murid) di kelas arus perdana dan belajar bersama-sama dengan murid arus perdana secara sepenuh masa dengan mengikuti semua pembelajaran mata pelajaran akademik seperti murid arus perdana berasaskan kurikulum kebangsaan atau kurikulum kebangsaan yang diubah suai. MBK turut terlibat dalam aktiviti kokurikulum sebagaimana murid arus perdana yang lain. Rekod kehadiran MBK PPKI (Program Pendidikan Khas Integrasi) yang mengikuti inklusif penuh direkodkan di kelas arus perdana. Berbeza dengan jenis inklusif separa. MBK ditempatkan ke inklusif separa (didaftarkan dalam APDM kelas PPKI) dan belajar sekurang-kurangnya satu mata pelajaran akademik seperti mata pelajaran bahasa Inggeris, bahasa Melayu atau mata pelajaran elektif atau terlibat dalam kegiatan kokurikulum bersama-sama murid arus perdana dan berjadual. Pada waktu yang selebihnya murid tersebut akan berada di kelas pendidikan khas seperti biasa. Rekod kehadiran MBK yang mengikuti inklusif separa dicatat pada kehadiran PPKI (Program Pendidikan Khas Integrasi).

Murid berkeperluan khas (MBK) yang mengikuti program pendidikan inklusif menerima pembelajaran berdasarkan Kurikulum Kebangsaan. Ini bermakna guru perlu berkemahiran dalam menggunakan pedagogi pengajaran yang bersesuaian dengan keperluan MBK yang ada di kelas tersebut. Webster's New World College Dictionary (2000), mendefinisikan pedagogi inklusif adalah amalan pedagogi yang dilaksanakan dalam persekitaran interaktif, di mana penglibatan pelajar adalah secara aktif. Pedagogi inklusif memberi peluang kepada semua pelajar tanpa mengira jantina, status sosioekonomi, bangsa, latar belakang etnik atau keupayaan fizikal dan kognitif untuk menguasai sesuatu konsep dan kemahiran. Hal ini bermaksud bahawa guru yang mengamalkan pedagogi inklusif telah bersedia untuk melibatkan MBK sebagai ahli komuniti dalam kelas tanpa pengasingan mana-mana pihak. Guru akan bertanggungjawab terhadap semua murid di dalam kelas dan berusaha untuk mencari jalan bagi melibatkan semua murid dalam proses pembelajaran dan pengajarannya (PdP) (Florian \& BlackHawkins, 2011; Spratt \& Florian, 2013). Dapatan kajian mendapati $73.2 \%$ guru di Malaysia sangat bersetuju untuk mengubah susunan fizikal di dalam kelas untuk menampung murid berkeperluan khas mereka. Kajian ini menunjukkan bahawa guru arus perdana menunjukkan komitmen dan menyokong untuk menerima murid berkeperluan khas di bilik darjah mereka (Abdul Rahim \& Muhamad Khairul, 2013).

Kajian ini melihat pelaksanaan pedagogi inklusif di sekolah arus perdana dengan menempatkan MBK dalam kelas arus perdana secara inklusif separa. Namun demikian didapati terdapat permasalahan apabila guru arus perdana tidak menguasai kemahiran mengendalikan pedagogi inklusif dengan baik. 
Hasil kajian lepas mendapati terdapat $60 \%$ guru masih menggunakan teknik dan kaedah pembelajaran dan pengajaran $(\mathrm{PdP})$ yang sama untuk semua murid di kelas dan tidak memperoleh pengetahuan mengenai pedagogi inklusif (Norliah \& Mohd Hanafi, 2016). Terdapat kekurangan dari segi amalan strategi pengajaran, akomodasi atau adaptasi yang khusus terhadap PdP yang dijalankan (Grace et al., 2012; Yuen, Westwood \& Wong, 2005; Johnstone, 2009). Kajian yang dijalankan oleh guru-guru perdana di Nova Scotia, Kanada mendapati tidak yakin dengan kebolehan mereka untuk mengajar dan mengadaptasi kurikulum yang sesuai dengan tahap keperluan murid-murid khas yang ada di kelas tersebut (Edmunds, 1998).

Justeru itu, hasil daripada kenyataan yang telah dikemukakan, menggambarkan bahawa terdapat isu berkaitan amalan pengajaran guru terhadap pendidikan inklusif yang menimbulkan ketegangan dalam menyediakan keperluan perkhidmatan murid di dalam kelas tersebut. Realiti pendidikan inklusif di sekolah harus diperhalusi khususnya aspek pedagogi yang dilaksanakan di sekolah. Terdapat ketidakpastian yang mendalam tentang bagaimana mewujudkan persekitaran inklusif di sekolah dan bagaimana pengajaran secara inklusif dapat dilaksanakan kerana wujudnya jurang antara realisasi dan formulasi pendidikan inklusif (Peder, 2017). Proses pengajaran yang berkesan apabila pelaksanaan pedagogi dapat memberi kesan khususnya kepada perkembangan MBK sekali gus menyokong pembelajaran semua murid di dalam kelas inklusif tersebut. Kepentingan kajian ini diharapkan dapat menyumbang kepada peningkatan amalan pengajaran guru melalui pendekatan atau gaya PdP mereka. Ini sangat penting bagi meningkatkan ilmu pengetahuan dan membantu merancang keperluan kursus profesionalisme kepada guru-guru arus perdana agar dapat melaksanakan PdP dengan lebih efisien, terbaik dan berkesan pada masa akan datang.

Objektif kajian ini adalah untuk melihat sejauh mana pelaksanaan pedagogi inklusif di kalangan muridmurid pendidikan khas dari kategori masalah pembelajaran di sebuah sekolah rendah. Objektif kajian ini adalah untuk:

i. Mengkaji pelaksanaan pedagogi inklusif yang digunakan terhadap murid masalah pembelajaran dalam Program Pendidikan Inklusif.

ii. Meninjau kesan pedagogi inklusif yang digunakan kepada perkembangan sosial murid masalah pembelajaran.

\section{Sorotan Literatur}

\section{Model Pengajaran Fasa Le Francois}

Model Le Francois merupakan satu model yang memerlukan penguasaan kemahiran sesuatu fasa di dalam mata pelajaran. Terdapat tiga fasa dalam model ini iaitu sebelum, semasa dan selepas. Bermula dengan sebelum pengajaran, guru akan membuat persediaan dengan menentukan objektif dan matlamat pengajaran yang ingin dicapai. Selain itu, mengambil kira kesediaan pelajar juga sangat penting bagi membolehkan murid dapat memberi respons yang positif semasa sesi PdP berlaku. Guru juga perlu menentukan strategi pengajaran yang akan digunakan dan menilai semula strategi pengajaran itu sama ada bersesuaian atau tidak dengan keperluan murid yang ada di dalam kelas tersebut. Peringkat kedua iaitu semasa pengajaran. Setelah guru memilih strategi pengajaran, guru akan melaksanakan strategi dan prosedur pengajaran dengan baik dan berkesan. Dan peringkat terakhir iaitu selepas pengajaran. Guru akan membuat refleksi terhadap keberkesanan strategi pengajaran yang telah dipilih dan telah dilaksanakan. Penambahbaikan dan pengubahsuaian akan sering berlaku dari semasa ke semasa supaya pada sesi pengajaran yang seterusnya akan berlaku lebih baik.

Melalui model ini dapat dikaitkan dengan pelaksanaan pedagogi inklusif dengan menggunakan langkah-langkah yang sistematik serta membuat persediaan sebelum, semasa dan selepas sesuatu pengajaran atau aktiviti. Sebelum pelaksanaan PdP, keperluan pembelajaran murid boleh dikenal pasti menerusi penilaian atau pentaksiran yang boleh dilaksanakan pelbagai cara sama ada melalui pemerhatian, temu bual dengan murid, ibu bapa atau guru yang pernah mengajar murid tersebut, ujian ringkas atau merujuk kepada Rancangan Pendidikan Individu Murid (RPI). Selain itu, amalan pembudayaan inklusif juga perlu dilaksanakan apabila guru menjelaskan kepada murid arus perdana 
bahawa terdapat murid yang mempunyai tahap keupayaan yang berbeza. Guru boleh merancang kandungan PdP mengikut topik yang sama melalui jenis aktiviti dan tahap murid yang berbeza bagi memenuhi keperluan pembelajaran murid yang pelbagai. Seterusnya semasa pelaksanaan PdP guru perlu mengamalkan teknik PdP yang berkesan. Ini termasuklah pendekatan PdP yang berpusatkan murid dengan menggalakkan penyertaan murid di dalam kelas. Aktiviti kumpulan merupakan satu contoh aktiviti yang boleh dilaksanakan yang dapat memberi manfaat kepada murid MBK/MBT. Selain itu, komunikasi berkesan juga adalah penting bagi menggalakkan peningkatan kemahiran mendengar, kemahiran kefahaman dan penghasilan bahasa serta menggalakkan penglibatan murid secara aktif di dalam kelas. Selepas pelaksanaan PdP, guru perlu membuat pentaksiran pemahaman MBK/MBT secara berkala dengan cara menggalakkan mereka menjelaskan hasil kerja/aktiviti yang sedang atau telah mereka laksanakan. Hasil daripada pentaksiran tersebut, penilaian dan refleksi dapat dilihat bagi melakukan penambahbaikan yang boleh dilaksanakan. Misalnya guru perlu mempunyai carta pencapaian atau rekod pencapaian MBK/MBT bagi tujuan pemantauan perkembangan murid dan carta ini boleh diubah serta dikemas kini berdasarkan perubahan yang ditunjukkan oleh murid.

\section{Pedagogi inklusif}

Pedagogi inklusif merupakan satu strategi pengajaran yang boleh membantu menyediakan peluang hak kesamarataan dalam pembelajaran yang sama kepada semua murid di bilik darjah. Pengajaran guru yang mengamalkan pedagogi inklusif perlu mengambil kira kepelbagaian murid di bilik darjah. Guru perlu optimis dalam mewujudkan suasana pembelajaran inklusif dengan mengamalkan strategi pengajaran yang melibatkan pendekatan yang menangani keperluan murid daripada pelbagai latar belakang, kebolehan dan gaya pembelajaran murid. Pedagogi inklusif dapat didefinisikan kepada keseluruhan kaedah, pendekatan, bentuk dan prinsip pengajaran yang digunakan bagi meningkatkan penyertaan semua pelajar (Makoelle, 2014). Walau bagaimanapun, terdapat pendebatan yang menjadi persoalan adakah pedagogi yang digunakan bersifat inklusif (Florian, 2009).

Pedagogi inklusif mempunyai pelbagai definisi dan tidak mempunyai satu definisi yang nyata. Makoelle (2014) mendapati sebahagian sarjana tidak bersetuju terdapat konsep pengajaran yang sepenuhnya inklusif. Namun terdapat pendebatan lain, bahawa pedagogi inklusif telah banyak didapati melalui kajian-kajian tentang pendidikan untuk semua murid di dalam kelas tanpa ada pengasingan (Hart et al., 2007). Dapatan kajian-kajian terdahulu mendapati adanya perbezaan di antara pedagogi biasa dengan pedagogi inklusif. Hal ini demikian kerana terdapat keraguan mengenai adakah bilik darjah arus perdana dapat memberikan pendidikan berkualiti yang optimum kepada kanak-kanak kurang upaya (Majoko, 2005; Yadav et al., 2015). Mengikut pandangan penyelidik pedagogi inklusif, mereka berpendapat sebenarnya tiada pedagogi yang khusus untuk MBK kecuali dalam kes tertentu seperti murid kurang upaya penglihatan dan juga pendengaran. Strategi dan teknik pengajaran yang berkesan terhadap MBK akan juga berkesan terhadap semua murid Ang dan Lee (2018). Oleh itu ia bergantung pada sikap, pengetahuan, kemahiran, kecekapan dan pemahaman positif guru (Ballard, 2012); Bhatnagar \& Das, 2013; Florian, 2014). Pedagogi inklusif dapat dibezakan apabila cara pengajaran guru itu menerima perbezaan keperluan murid yang ada di dalam kelas itu (Florian, 2016). Sebagai contoh, murid berkeperluan khas masalah pendengaran yang memasuki ke dalam kelas perdana yang ada sokongan tambahan guru pakar masalah pendengaran. Cara amalan pengajaran guru itu sendiri menentukan sama ada pengajaran itu bersifat inklusif atau tidak. Sekiranya guru pakar mengambil pendekatan pengajaran berkumpulan, supaya pelajar masalah pendengaran tidak terpencil dengan kehadiran seorang guru pakar tambahan maka sokongan itu dapat memberi bermanfaat. Di sini, inilah cara guru bekerjasama untuk memastikan bahawa tidak ada murid yang terpinggir di dalam kelas.

Hasil kajian lepas membuktikan terdapat peningkatan kesan daripada pencapaian MBK terhadap pedagogi yang digunakan oleh guru. Ini dapat dilihat apabila kaedah pembelajaran secara berkumpulan telah digunakan dalam fasa pengajaran bagi meningkatkan interaksi sosial di kalangan mereka (Mazmi \& Syahira, 2019). Selain itu, peningkatan kemahiran sosial MBK apabila dapat memberi respons terhadap soalan guru secara spontan dan dapat bersosialisasi dengan baik bersama murid arus perdana (Norliah \& Mohd Hanafi, 2016). Ini sekali gus kaedah yang digunakan oleh guru telah berjaya menarik perhatian murid inklusif untuk terlibat secara aktif dalam aktiviti pembelajaran. Justeru, adalah amat 
penting elemen pedagogi inklusif ditekankan bagi memberi peluang dan ruang bagi semua murid yang diinklusifkan melakukan aktiviti pembelajaran bersama murid arus perdana tanpa mengira perbezaan latar belakang. Penglibatan semua murid tanpa mengira latar belakang dan kekurangan akan dapat mewujudkan persekitaran sosio emosi yang lebih kondusif (Booth et al., 2000).

\section{Metod Kajian}

\section{Reka bentuk kajian}

Reka bentuk kajian ini adalah kajian kes dengan pendekatan kualitatif. Rasional pengkaji memilih kajian kes adalah bagi membantu pengkaji mendapatkan data secara terperinci hasil daripada penerokaan dalam persekitaran sebenar untuk membina kenyataan dan penerangan berkaitan bidang kajian mengenai pelaksanaan pedagogi inklusif bagi murid berkeperluan khas masalah pembelajaran. Kajian kes adalah satu penyelidikan yang mengkaji fenomena yang terjadi dalam konteks sebenar (Yin, 1994).

\section{SampelKajian}

Kaedah pensampelan yang digunakan adalah persampelan bertujuan. Penggunaan persampelan bertujuan adalah untuk membolehkan pengkaji menentukan responden yang sesuai dan khusus dengan tujuan kajiannya. Penyelidik perlu menggunakan pertimbangannya sendiri untuk memilih responden yang paling sesuai dengan kajiannya (Reinard, 2001). Dari sudut pemilihan sampel, peserta kajian telah dipilih berdasarkan dua kriteria iaitu sekurang-kurangnya memegang satu kelas inklusif semasa kajian ini dijalankan, dan mempunyai pengalaman mengajar kelas inklusif 1 hingga 2 tahun.

\section{Skop Kajian}

Lokasi kajian yang dipilih ialah di sebuah sekolah rendah di negeri Johor. Pengkaji melimitasikan lokasi kajian disebabkan data kajian yang dikumpulkan memerlukan pertemuan yang berulang maka pengkaji memilih dari satu lokasi sahaja untuk memudahkan pengkaji mendapatkan data dan maklumat dari peserta kajian sekiranya maklumat yang didapati tidak mencukupi. Sekolah yang dikaji juga merupakan sekolah rintis bagi Program Pendidikan Inklusif model holistik peringkat negeri Johor.

\section{Instrumen Kajian}

Instrumen kajian yang digunakan adalah protokol temu bual. Protokol temu bual digunakan untuk memahami persoalan, proses dan situasi yang diselidiki. Di samping itu, dapat membantu pengkaji memberi fokus kepada pengalaman yang diceritakan oleh peserta kajian dan soalan yang mengarah kepada fokus kajian (Ong et al., 2017).

\section{Hasil Kajian}

\section{Demografi peserta kajian}

Jadual 1 di bawah menunjukkan peserta kajian yang dipilih terdiri daripada tiga orang peserta kajian berumur 40-50an ke atas dan mempunyai pengalaman dalam pendidikan melebihi 20 tahun ke atas. Jantina peserta kajian terdiri daripada dua orang perempuan dan seorang lelaki. Dua orang peserta kajian mempunyai Ijazah Sarjana Muda Pendidikan dan seorang peserta kajian mempunyai Diploma Pendidikan dalam Bidang Perguruan. Jika dilihat subjek pengkhususan yang diambil, ketiga-tiga peserta kajian tidak mempunyai pendedahan secara formal mengenai pendidikan inklusif semasa peringkat pengajian di IPT/IPG. Dua orang peserta kajian mengajar mata pelajaran elektif iaitu Pendidikan Seni Visual (PSV) dan Pendidikan Jasmani dan Pendidikan Kesihatan (PJPK) manakala 
seorang peserta kajian mengajar mata pelajaran teras iaitu Bahasa Melayu. Ketiga-tiga nama peserta kajian adalah bukan nama sebenar yang digunakan dalam kajian ini.

Jadual 1: Demografi peserta kajian

\begin{tabular}{|c|c|c|c|c|c|c|c|}
\hline $\begin{array}{l}\text { Peserta } \\
\text { Kajian }\end{array}$ & Umur & Jantina & $\begin{array}{c}\text { Kelayakan } \\
\text { akademik }\end{array}$ & $\begin{array}{c}\text { Subjek } \\
\text { yang } \\
\text { diajar }\end{array}$ & $\begin{array}{c}\text { Pengalaman } \\
\text { mengajar }\end{array}$ & $\begin{array}{c}\text { Pengalaman } \\
\text { Program } \\
\text { Pendidikan } \\
\text { Inklusif }\end{array}$ & $\begin{array}{c}\text { Umur murid } \\
\text { yang } \\
\text { diinklusifkan }\end{array}$ \\
\hline $\begin{array}{l}\text { Cikgu } \\
\text { Zurina }\end{array}$ & $\begin{array}{c}58 \\
\text { tahun }\end{array}$ & $\mathrm{P}$ & $\begin{array}{c}\text { Diploma } \\
\text { Pendidikan } \\
\text { (Pengajian } \\
\text { Am) }\end{array}$ & $\begin{array}{c}\text { Mengajar } \\
\text { subjek } \\
\text { Bahasa } \\
\text { Melayu }\end{array}$ & 36 tahun & 1 tahun & 13 tahun \\
\hline $\begin{array}{l}\text { Cikgu } \\
\text { Zainab }\end{array}$ & $\begin{array}{c}52 \\
\text { tahun }\end{array}$ & $\mathrm{P}$ & $\begin{array}{c}\text { Ijazah } \\
\text { Sarjana } \\
\text { Muda } \\
\text { (Bimbingan } \\
\text { Kaunseling } \\
\text { dan Bahasa } \\
\text { Melayu) }\end{array}$ & $\begin{array}{l}\text { Mengajar } \\
\text { subjek } \\
\text { Pendidikan } \\
\text { Seni } \\
\text { Visual }\end{array}$ & 26 tahun & 1 tahun & 14 tahun \\
\hline $\begin{array}{l}\text { Cikgu } \\
\text { Azfar }\end{array}$ & $\begin{array}{c}49 \\
\text { tahun }\end{array}$ & $\mathrm{L}$ & $\begin{array}{c}\text { Ijazah } \\
\text { Sarjana } \\
\text { Muda } \\
\text { (Pendidikan } \\
\text { Muzik dan } \\
\text { Seni } \\
\text { Visual) }\end{array}$ & $\begin{array}{l}\text { Mengajar } \\
\text { subjek } \\
\text { PJPK }\end{array}$ & 24 tahun & 2 tahun & 14 tahun \\
\hline
\end{tabular}

Dapatan kajian mendapati terdapat tiga fasa dalam pelaksanaan pedagogi inklusif iaitu sebelum, semasa dan selepas yang diadaptasi dari Model pengajaran Le Francois sebagai panduan dalam kajian yang dijalankan. Terdapat empat model pengajaran dalam pedagogi pendidikan inklusif yang digunakan oleh peserta kajian iaitu: Model sosial: Pembelajaran Koperatif dan Pembelajaran Aktif, Model Peribadi/Kendiri : Non-Directive Teaching Model, Model Tingkah Laku : Kaedah bercerita dan Model Pengajaran Bersama : Supportive Co-Teaching.

\section{Pelaksanaan pedagogi inklusifCikgu Zurina}

Sebelum melaksanakan PdP, Cikgu Zurina yang mempunyai pengalaman mengajar melebihi 30 tahun telah membuat perbincangan bersama guru pendidikan khas (guru pendamping atau guru resos) mengenai topik yang akan diajar. Semasa pelaksanaan aktiviti, Cikgu Zurina telah menggunakan dua kaedah pedagogi inklusif iaitu kaedah bercerita dan kaedah pengajaran bersama dalam melaksanakan pembelajaran dan pengajaran (PdP). Kaedah bercerita adalah satu kaedah bagi menggalakkan murid berkomunikasi dengan lebih baik. Kaedah ini juga sangat sesuai digunakan bagi MBK yang mempunyai masalah interaksi sosial yang boleh diterapkan dalam mata pelajaran. Di peringkat aliran perdana, kaedah bercerita merupakan aktiviti pembelajaran yang menyeronokkan ke arah pembangunan dan pembentukan karakter murid. Kaedah kedua yang digunakan adalah kaedah pengajaran bersama iaitu supportive co-teaching. Kaedah ini merupakan satu kaedah pengajaran yang mana guru pendidikan khas dan guru arus perdana bekerjasama untuk melaksanakan objektif PdP yang ditetapkan dalam suatu isi pelajaran. Selepas pelaksanaan aktiviti, Cikgu Zurina bersama guru pendidikan khas telah membincangkan hasil daripada penilaian dan pentaksiran yang telah dibuat sepanjang sesi PdP dijalankan. Pentaksiran yang dilakukan secara berkala dengan cara menggalakkan MBK menceritakan hasil kerja/aktiviti yang telah dilakukan. 


\section{Pelaksanaan pedagogi inklusifCikgu Zainab}

Cikgu Zainab merupakan seorang guru yang komited dalam melaksanakan pengajaran kepada muridmuridnya. Sebelum melaksanakan PdP, telah membuat perancangan yang strategik dengan membuat perbincangan bersama guru pendidikan khas mengenai topik yang akan diajar. Dalam melaksanakan pedagogi inklusif, kaedah yang digunakan oleh Cikgu Zainab adalah kaedah pembelajaran koperatif dan pembelajaran secara aktif. Kedua-dua kaedah telah banyak membantu Cikgu Zainab dalam melaksanakan PdP supaya mencapai objektif yang telah ditetapkan dalam isi pelajaran. Apabila kedua kaedah ini digabungkan maka menjadikan pengajaran guru lebih berkesan dan pembelajaran murid lebih bermakna. Selain itu, kaedah pembelajaran secara kendiri iaitu Non-Directive Teaching Model merupakan satu kaedah yang digunakan oleh Cikgu Zainab yang dapat membantu murid untuk berfikir secara kritis dan kreatif bagi memaksimumkan kebolehan yang murid ada. Melalui kaedah ini, murid diberi kebebasan untuk cuba mengeluarkan idea sendiri berdasarkan pengetahuan sedia ada mereka. Kaedah ini didapati sangat efektif jika dibandingkan dengan maklumat yang disampaikan secara 'spoon feeding' oleh guru tanpa sebarang usaha untuk cuba mengeluarkan idea. Kaedah yang seterusnya adalah kaedah pengajaran bersama (co-teaching) iaitu supportive co-teaching. Melalui kaedah ini guru dapat mempertingkatkan kemahiran pedagogi guru apabila setiap guru mempunyai kekuatan dan kelemahan yang tersendiri, maka melalui kaedah pengajaran bersama murid-murid bertuah kerana dapat menerima pengajaran dua orang guru yang saling melengkapi. Guru pendidikan khas dan guru arus perdana menggembleng tenaga untuk melaksanakan PdP bagi memenuhi keperluan khusus kepada kedinamikan kebolehan dan keupayaan dalam bilik darjah. Selepas pelaksanaan aktiviti, Cikgu Zainab bersama guru pendidikan khas mencari masa untuk membincangkan hasil daripada penilaian dan pentaksiran yang telah dibuat sepanjang PdP dijalankan. Ini bagi memudahkan Cikgu Zainab dan guru pendidikan khas membuat intervensi atau tindakan susulan serta merta bagi mengatasi kelemahan dan mempertingkatkan kekuatan PdP.

\section{Pelaksanaan pedagogi inklusifCikgu Azfar}

Cikgu Azfar merupakan seorang guru senior dalam Program Pendidikan Inklusif. Sebelum melaksanakan PdP, Cikgu Azfar telah membuat perancangan dari segi topik yang akan diajar dan membuat perbincangan bersama guru pendidikan khas bagi mengetahui kesesuaian topik itu dengan MBK. Semasa pelaksanaan PdP, kaedah yang digunakan oleh Cikgu Azfar adalah kaedah pembelajaran koperatif dan aktif. Bagi mata pelajaran PJPK, dua kaedah ini sangat sesuai digunakan dalam PdP di kelas. Subjek PJPK memerlukan kerjasama dan penglibatan yang aktif bagi semua murid supaya dapat menimbulkan minat seterusnya keseronokan berterusan kepada murid untuk menjadikan proses pengajaran lebih berkesan. Pelajar akan mendapat keseronokan apabila mereka dapat menguasai sendiri setiap kemahiran yang dipelajari melalui kaedah berpusatkan murid dan aktiviti dilakukan secara ansur maju.

Selain itu, kaedah yang digunakan oleh Cikgu Azfar adalah kaedah pengajaran bersama iaitu supportive co-teaching. Kaedah pengajaran bersama telah banyak diguna pakai dalam proses pengajaran dan pembelajaran di Malaysia kerana ia telah dapat memudahkan murid belajar dan guru untuk merangka serta melaksanakan sebuah aktiviti pengajaran dan pembelajaran yang lebih berkesan. Selain itu, kaedah ini juga memberi manfaat bagi kelas yang mempunyai MBK. Hal ini disebabkan seorang guru yang menjadi pemimpin dan seorang guru lagi menjadi pembantu. Mereka mempunyai tanggungjawab masing-masing apabila dalam sesi PdP. Selepas pelaksanaan aktiviti, Cikgu Azfar membuat rumusan atau refleksi pembelajaran bersama murid mengenai isi pelajaran yang dipelajari. Setelah itu, perbincangan bersama guru pendidikan khas dengan menggunakan amalan Lesson study yang merupakan salah satu amalan pelaksanaan aktiviti pengajaran dan persediaan secara kolaborasi. Cikgu Azfar dan guru pendidikan khas bersama-sama membincangkan isu yang timbul bagi mencari jalan penyelesaian dan merancang serta menyedia rancangan mengajar sebelum melaksanakan PdP pada hari yang berikutnya. 


\section{Kesan Pedagogi Inklusif Kepada Perkembangan Sosial Murid Berkeperluan Khas Masalah Pembelajaran}

Terdapat pelbagai kesan kepada perkembangan sosial MBK berdasarkan amalan model-model pengajaran yang digunakan. Ketiga-tiga peserta kajian mengetengahkan kelebihan dari aspek kemahiran sosial MBK. Kemahiran sosial adalah sebarang reaksi kognitif atau tingkah laku yang boleh dilihat semasa individu berinteraksi dengan individu lain (Elksnin \& Elksnin, 2006). Kemahiran sosial boleh dilihat daripada tingkah laku bekerjasama, berdikari, persahabatan, tindak balas terhadap sesuatu aktiviti dan melakukan perkara yang diharap oleh orang dewasa Rohani Abdullah (2001). Penempatan MBK ke dalam kelas inklusif telah banyak meningkatkan kemahiran sosial mereka apabila dapat membina hubungan yang baik dengan murid arus perdana menerusi aktiviti-aktiviti dalam proses pengajaran dan pembelajaran yang melibatkan interaksi serta kerjasama antara mereka bersama-sama murid arus perdana yang lain. Berdasarkan pelaksanaan pedagogi inklusif yang digunakan oleh peserta kajian, terdapat lima aspek kemahiran sosial yang dapat diperincikan.

\section{Aspek keyakinan diri}

Kemahiran sosial murid dari aspek keyakinan diri dapat dilihat dari segi penglibatan diri seseorang pelajar dalam proses pembelajaran. Keyakinan diri adalah melakukan sesuatu tingkah laku dengan jayanya tanpa mempunyai perasaan risau, penilaian positif terhadap diri sendiri, dan mengharap pencapaian yang positif Parnabas et al. (2013). Ketiga-tiga peserta kajian telah membincangkan mengenai peningkatan kemahiran sosial dari aspek keyakinan diri. Sebagai contoh:

“...MBK telah menunjukkan keyakinan yang tinggi dalam diri seperti mengangkat tangan untuk memberikan respon atau maklum balas dengan soalan yang diberikan..."

\section{Aspekbekerjasama}

Proses PdP yang menggalakkan kerjasama dalam kelas atau sesama ahli kumpulan dapat memberi kesan yang positif terhadap pencapaian pelajar. Hubungan kerjasama dapat diwujudkan apabila murid dapat membantu antara satu sama lain, membolehkan pertukaran idea dan pandangan antara murid dalam kumpulan. Pengajaran secara berkumpulan juga dikenali sebagai pengajaran koperatif, pengajaran kolaboratif atau bersama Eaton, Salmon dan Wischnowski (2004). Ketiga-tiga peserta kajian telah membincangkan mengenai peningkatan dari aspek bekerjasama. Sebagai contoh:

“...Murid arus perdana dan MBK memerlukan sikap saling kebergantungan yang positif dikalangan ahli kumpulan untuk menyelesaikan sesuatu masalah atau tugasan..."

\section{Aspek Penyertaan Bersama}

Penyertaan bersama oleh MBK dan murid arus perdana telah memberi kelebihan kepada MBK bagi membantu mengembangkan potensi dan meningkatkan kemahiran mereka terutama kemahiran sosial. Hal ini demikian kerana, kaedah yang digunakan telah berupaya menjadikan murid lebih bermotivasi untuk belajar dan sama-sama turut serta dengan aktiviti yang dirancangkan oleh guru. Cikgu Zainab satu-satunya yang berpendapat bahawa aspek penyertaan bersama antara MBK dan murid arus perdana telah berlakunya peningkatan dari segi kemahiran sosial. Sebagai contoh:

“...Penglibatan murid secara aktif khususnya dalam aktiviti berkumpulan dapat meningkatkan kemahiran sosial serta memupuk semangat atau nilai positif dalam diri mereka..." 


\section{Aspek perkongsianidea}

Perkongsian idea dalam PdP dapat memberi impak kepada pencapaian murid dari segi peningkatan kemahiran sosial mereka. MBK dan murid tipikal berbincang serta berkongsi bahan, pengalaman dan kreativiti dengan rakan-rakan yang lain. Pelbagai kaedah atau pendekatan boleh digunakan oleh guru mengikut kreativiti dan kesesuaian pelajar dan juga boleh dikaitkan dengan tema pembelajaran masa kini iaitu Pembelajaran Abad Ke-21(PAK-21). Cikgu Zainab satu-satunya peserta kajian yang telah berpendapat bahawa aspek perkongsian idea dapat memberi peluang kepada mereka untuk bersosialisasi dengan lebih baik. Sebagai contoh :

“... Pembelajaran secara kendiri telah memaksimumkan penglibatan semua murid apabila MBK dan arus perdana bersama-sama berbincang dan berkongsi idea atau pendapat..."

\section{Aspek Berdikari}

Melalui pedagogi inklusif yang diaplikasikan oleh guru dapat memberi pendedahan kepada MBK untuk hidup berdikari dan bersosial selain mengenal persekitaran lain supaya tidak terkongkong dengan persekitaran di kelas pendidikan khas sahaja. Ketiga-tiga peserta kajian telah menyatakan bahawa aspek ini sangat penting bagi memenuhi keperluan kehidupan luar yang lebih mencabar nanti. Contohnya :

“...Kebergantungan kepada guru pendidikan khas semakin berkurangan apabila MBK sudah mula menyesuaikan diri dengan persekitaran di lingkungan sosial mereka seperti pergi ke kantin dengan sendiri..."

\section{Perbincangan Kajian}

\section{Kepelbagaian dalam Pelaksanaan Pedagogi Inklusif bagi MBK Masalah Pembelajaran}

Secara keseluruhannya, hasil kajian menunjukkan bahawa kesemua peserta kajian menggunakan pelbagai kaedah pedagogi inklusif dalam melaksanakan pendidikan inklusif di kalangan murid masalah pembelajaran. Ini dibuktikan dengan hasil analisis temu bual bersama peserta kajian yang menunjukkan bahawa terdapat model-model dalam kaedah pengajaran dan pembelajaran (PdP) yang digunakan bagi menjanakan hasil yang diingini dalam proses pembelajaran murid. Dalam melaksanakan pedagogi inklusif, guru perlu berkemahiran untuk mengadaptasi kurikulum dan bahan pengajaran supaya objektif PdP yang dirancang dapat dicapai oleh semua murid di dalam kelas. Walaupun begitu, terdapat beberapa penyelidik pedagogi inklusif tidak begitu menerima pandangan bahawa adanya pedagogi khas, sebenarnya terdapat juga bidang penyelidikan lain yang berfokus khusus kepada pedagogi khas yang didapati sesuai dengan kategori MBK yang tertentu (Ang \& Lee, 2018). Sebagai contoh, strategi dan teknik dalam Picture Exchange Communication System yang menyasarkan untuk mengajar murid autistik (Frost \& Bondy, 2002). Namun demikian, pedagogi khas ini berasaskan kepada elemen asas teori -teori pembelajaran seperti strategi berasaskan visual, strategi mengajar mengikut urutan kecil dan strategi peneguhan positif. Guru yang berpegang kepada pedagogi inklusif, tidak akan mengabaikan pengetahuan dan kemahiran pedagogi khas, malahan akan lebih berikhtiar untuk mengintegrasikan elemen-elemen daripada pedagogi khas secara autentik di dalam kelas supaya berfaedah untuk semua murid dan bukannya hanya untuk MBK sahaja (Ang \& Lee, 2018). Ianya bergantung pada sikap, pengetahuan, kemahiran, kecekapan dan pemahaman positif guru terhadap pedagogi inklusif (Ballard, 2012; Bhatnagar \& Das, 2013; Florian, 2014).

Dapatan kajian mendapati peserta kajian telah membuat perancangan dan perbincangan sebelum melaksanakan PdP. Ini dapat mengembangkan lagi idea berkaitan dengan perancangan dan perbincangan yang telah dilaksanakan oleh peserta kajian apabila guru membuat ulang kaji dan 
persediaan dari segi bahan pembelajaran dan lain-lain. Seperti mana yang dikemukakan oleh Amir Hasan (2002) menyatakan, dalam sebuah bilik darjah, setiap individu mempunyai psikologi dan kebolehan intelek yang berbeza antara satu sama lain. Lantaran itu pengajaran yang dirancang perlu sesuai, disusun (mengikut tahap pelajar) dan disokong (dengan alat bantu mengajar) bagi merangsang perkembangan potensi individu ke tahap yang maksimum. Dapatan kajian menunjukkan bahawa kaedah pembelajaran secara koperatif dan pembelajaran secara aktif merupakan kaedah dari model sosial yang mampu menggalakkan penglibatan murid secara aktif dan hubungan kerjasama dapat diwujudkan. Apabila kedua dua kaedah ini digunakan bersama dapat mengoptimumkan pembelajaran yang lebih memberangsangkan. Seperti mana yang dikemukakan Zamri (2014), menyatakan bahawa pembelajaran koperatif adalah satu cara yang terbaik untuk digunakan. Dalam pendidikan inklusif, kaedah pembelajaran seperti ini sangat bermanfaat kepada MBK. Apabila MBK ini ditempatkan bersama dalam kelas inklusif membolehkan mereka turut serta secara aktif dalam aktiviti yang dilaksanakan serta membina keyakinan untuk berinteraksi dengan murid arus perdana dan rasa diterima dalam kelompok tersebut. Oleh itu, pendidikan inklusif memberi banyak peluang kepada murid untuk berkomunikasi setiap hari (Alper et al., 2001). Namun demikian, kaedah seperti ini memerlukan pengurusan masa yang lebih panjang bagi membolehkan kaedah seperti dapat memberi manfaat kepada semua murid. Terdapat permasalahan apabila menggunakan kaedah ini apabila guru tidak cukup masa untuk memberi penerangan dan pembahagian bahan dan tugasan. Pelaksanaan pembelajaran koperatif yang efisyen memerlukan komitmen yang tinggi daripada guru (Salimah, 2013). Guru perlu meluangkan lebih banyak masa persediaan untuk merancang pelan pengajaran terutama sekali apabila alat bantu mengajar seperti alat audio dan video adalah terhad.

Non-Directive Teaching Model merupakan kaedah dari model peribadi/kendiri. Model peribadi/ kendiri adalah satu model yang berpusatkan murid, guru berfungsi sebagai pemudah cara. Kaedah pembelajaran ini dapat menggalakkan peningkatan ilmu pengetahuan, kompetensi peribadi, perasaan dan kesedaran kendiri. Dalam kaedah ini banyak idea atau kelebihan yang boleh guru kembangkan bagi meningkatkan penguasaan murid terhadap sesuatu PdP yang dijalankan seperti memberi peluang kepada murid untuk meneroka dan bebas untuk mengeluarkan idea. Guru sebagai pemudah cara membimbing dan memaksimumkan lagi kebolehan murid untuk berfikir secara kreatif dan kritis. Seperti mana yang dikemukakan oleh Soh (2015), yang menyatakan aspek kebebasan merupakan tindakan guru menggalakkan muridnya belajar sesuatu tanpa bergantung kepada orang lain. Justeru itu, peranan guru sangat penting dalam menentukan kaedah pengajaran bagi menjadikan kelas lebih menarik serta menyeronokkan, sekali gus menggalakkan penjanaan idea dalam kalangan murid.

Kaedah bercerita merupakan satu kaedah dari model tingkah laku yang dapat membolehkan murid memahami sesuatu situasi sosial dengan penekanan kepada nilai-nilai murni dan tingkah laku yang menggunakan kiu visual. Dapatan kajian mendapati kaedah ini sangat sesuai digunakan bagi MBK bertujuan menggalakkan interaksi sosial berlaku dan boleh diterapkan di dalam mana-mana mata pelajaran yang menerapkan nilai-nilai murni seperti subjek Bahasa Melayu, Pendidikan Islam, Sivik / Moral. Seperti mana yang dikemukakan oleh Aisyah dan Nazri (2019) aktiviti bercerita mampu menjadikan sesuatu aktiviti pengajaran dan pembelajaran dengan berkesan. Hal ini kerana adanya penggunaan gambar bersiri atau papan cerita yang menarik dapat mewujudkan suasana PdP yang menyeronokkan, aktif dan menjana pemikiran murid.

Kaedah pengajaran bersama (co-teaching) dari model pengajaran bersama merupakan kaedah yang telah digunakan oleh ketiga-tiga peserta kajian dalam melaksanakan pedagogi inklusif. Pengajaran bersama dapat didefinisikan apabila dua atau lebih orang berkongsi tanggungjawab untuk mengajar sebilangan atau semua pelajar di dalam sebuah kelas (Villa et al., 2004). Kaedah ini melibatkan dua orang guru dalam satu kelas. Dapatan kajian menunjukkan bahawa mereka telah menggunakan kaedah pengajaran bersama iaitu bentuk pengajaran supportive co-teaching yang mana guru arus perdana mengetahui dalam kelas dan guru pendidikan khas sebagai pembantu dalam sesi PdP mereka. Pelaksanaan kaedah seperti ini dapat memberi manfaat kepada guru dalam mengembangkan idea berkaitan pedagogi inklusif terutama bagi bagi kelas yang mempunyai MBK. Seperti mana yang dikemukakan oleh Goldwriter dalam Linda Neas (2012), pengajaran bersama ini sangat berkesan kerana setiap guru mempunyai kekuatan dan kelemahan yang tersendiri, maka melalui kaedah 
pengajaran bersama murid-murid bertuah kerana dapat menerima pengajaran dua orang guru yang saling melengkapi.

Dapatan kajian menunjukkan bahawa terdapat perbezaan apabila guru menggunakan kaedah pembelajaran bersama apabila terdapat peningkatan dari segi kemahiran sosial murid seperti sudah yakin untuk bersosialisasi dalam ahli kumpulan, bertanggungjawab dalam diri, berdikari dalam menguruskan kehidupan. Seperti mana yang dikemukakan oleh kajian lepas O'Shea et al. (1999) kemahiran kolaborasi merupakan kunci keberkesanan pengajaran guru dalam kerja berpasukan. Oleh itu, apabila adanya kolaborasi antara guru, maka guru dapat merancang pengajaran yang lebih berkesan dan teratur (Dynak et al., 1997; Hudson \& Glomb, 1997).

Selepas pengajaran dan pembelajaran dilaksanakan, aspek yang ditekankan oleh peserta kajian adalah melakukan penilaian, pentaksiran dan refleksi berdasarkan pengajaran yang telah disampaikan sama ada ianya sesuai diamalkan atau perlu melakukan perubahan agar dapat disesuaikan dengan muridmurid di kelas inklusif. Pentaksiran dilakukan sama seperti murid arus perdana. Terdapat dua (2) komponen pentaksiran dalam pendidikan inklusif, iaitu Pentaksiran Bilik Darjah (PBD) dan Pentaksiran Pusat (PP). Kaedah pentaksiran bilik darjah dilakukan secara pemerhatian secara berterusan dan penilaian hasil kerja murid. Bagi menghasilkan PdP yang berkesan, guru perlu samasama membincangkan semula pengajaran mereka dengan guru yang lain atau pihak yang bertanggungjawab dan membuat penilaian diri mereka sendiri bagi mereka bentuk semula pengajaran mereka mengikut kesesuaian (Efi Paparistodemou et al., 2014).

\section{Kesan Pedagogi Inklusif Kepada Perkembangan Sosial Murid Berkeperluan Khas Masalah Pembelajaran}

Kepelbagaian kaedah yang telah digunakan telah memberi kesan khususnya kepada perkembangan MBK. Namun ketiga-tiga peserta kajian mengetengahkan kelebihan dari aspek kemahiran sosial MBK. Terdapat lima aspek kemahiran sosial yang dapat dikategorikan iaitu yang pertama aspek keyakinan diri. Dapatan kajian ini menunjukkan bahawa kaedah yang digunakan oleh peserta kajian telah membantu MBK meningkatkan rasa keyakinan dalam diri dengan melalui pengalamanpengalaman sosial dan interaksi-interaksi sosial bersama guru dan rakan-rakan di dalam kelas. Ini dapat dijelaskan bahawa guru berupaya melaksanakan PdP secara berkesan yang berjaya menarik perhatian murid khususnya murid inklusif untuk terlibat secara aktif dalam aktiviti pembelajaran. Seperti mana yang dikemukakan oleh Norliah dan Mohd Hanafi (2016) dalam kajiannya mendapati MBK dapat memberi respons terhadap soalan guru secara spontan. Ini menunjukkan murid berasa yakin dan berani memberi maklum balas terhadap soalan yang diberikan.

Yang kedua aspek bekerjasama juga dapat dibina berdasarkan kaedah yang dilaksanakan. Hal ini demikian kerana rakan sekumpulan juga boleh bertindak sebagai model pembelajaran. Apabila melihat rakan yang lain berjaya, mereka juga ingin berjaya dan dapat meningkatkan rasa sokongan kepada pelajar. Konsep belajar bersama-sama rakan merupakan salah satu elemen yang terdapat dalam pembentukan kepada kemahiran sosial murid dengan lebih baik. Sebagai contoh, pembelajaran secara koperatif dapat membantu murid meningkatkan lagi peluang bekerjasama di antara murid arus perdana dan MBK. Seperti mana yang dikemukakan oleh Efendi (1998), pengajaran koperatif adalah suatu strategi di mana murid-murid saling membantu antara satu sama lain di dalam kumpulan kecil. Pengajaran ini berlaku apabila pelajar bekerja secara berkumpulan, berkongsi idea, saling membantu untuk menyelesaikan masalah, dan memastikan semua ahli kumpulan menguasai isi pelajaran dengan meminta bantuan daripada guru. Namun, keadaan sebaliknya juga boleh berlaku seperti sebahagian pelajar takut untuk mengambil bahagian dalam kelas kerana bimbang tentang penerimaan rakan-rakan yang lain ataupun pelajar perempuan yang malu kepada pelajar lelaki dan sebagainya (Cajkler \& Addelman, 2000).

Yang ketiga aspek penyertaan bersama oleh MBK dan murid arus perdana dalam aktiviti secara berpasukan yang dijalankan telah memberikan peluang untuk mereka menyesuaikan diri dengan murid arus perdana. Ini penting bagi meningkatkan kemahiran kehidupan harian mereka khususnya persekitaran di luar sana yang memerlukan mereka berkomunikasi dan bersosialisasi dengan 
masyarakat atau komuniti yang besar. Dapatan kajian ini dapat mengembangkan lagi idea berkaitan dengan aktiviti secara berpasukan seperti mana yang dikemukakan oleh Zalika \& Faridah (2012) kerja berkumpulan atau secara sepasukan adalah selari dengan tuntutan agama dan juga tuntutan sosial bagi memenuhi keperluan sosial manusia.

Yang keempat perkongsian idea dalam PdP dapat memberi impak kepada pencapaian murid dari segi peningkatan kemahiran sosial mereka. Dapatan kajian menunjukkan bahawa kaedah pembelajaran secara kendiri ini adalah berpusatkan murid, mampu memberikan murid berfikir secara kreatif dan kritis serta dapat membina kemahiran personal murid apabila wujudnya komunikasi dan interaksi yang efektif. Sebagai contoh dalam Pendidikan Seni Visual. Pendidikan seni visual bukan lah seperti mata pelajaran yang lain. Dalam Dokumen Standard Pendidikan Seni Visual, adalah berpusatkan murid dan memberi peluang kepada mereka untuk mempertingkatkan daya imaginasi, kreativiti, dan bakat ke tahap optima dalam proses penghasilan karya (Nurul Ain et al., 2019). Aktiviti seperti ini mampu menggalakkan murid untuk berkongsi idea, pendapat dan sekali gus dapat meningkatkan interaksi sosial dan membina kemahiran komunikasi dan sosial di antara murid arus perdana di dalam kelas.

Yang kelima sikap berdikari dan kaedah yang digunakan telah menunjukkan peningkatan dari segi kemahiran sosial murid. MBK boleh berdikari dalam melakukan aktiviti rutin harian tanpa bantuan guru atau rakan di sekeliling. Mereka boleh belajar bertanggungjawab terhadap diri sendiri atas apa yang dilakukan. Sebagai contoh berdikari pergi ke tandas, mengambil barang di kelas, pergi ke kantin dan sebagainya. Seperti mana yang dikemukakan oleh Johnson (2006) mendapati bahawa murid sindrom down dan bermasalah pembelajaran teruk yang belajar di dalam bilik darjah Pendidikan Inklusif menunjukkan peningkatan yang positif apabila mereka mampu berdikari, boleh menggunakan bahasa dalam konteks yang sesuai dan boleh berkomunikasi. Justeru itu, melalui kaedah yang digunakan dapat membantu MBK meluaskan lagi lingkungan sosial mereka yang sebelum ini mereka hanya di kelompok di kelas pendidikan khas sahaja. Di kelas inklusif, MBK belajar untuk bersosialisasi dengan persekitaran yang berbeza yang dapat meningkatkan kemahiran sosial mereka dengan lebih baik. Peluang seperti ini bukan sahaja memberi manfaat di peringkat sekolah malah dapat memberi kebaikan apabila mereka berhadapan dengan alam yang lebih mencabar seperti alam pekerjaan. Pendidikan inklusif ini memberi peluang kepada mereka untuk berada dalam persekitaran masyarakat yang sebenar dan situasi ini akan membantu mereka melatih diri berhadapan dengan kehidupan masa depan kelak (Zaharah, 2013).

\section{Kesimpulan}

Dapatan kajian ini dapat disimpulkan bahawa terdapat kepelbagaian kaedah yang digunakan oleh peserta kajian yang telah menyokong pelaksanaan pedagogi inklusif selaras prinsip pendidikan pada masa kini. Guru perlu berpengetahuan dan berkemahiran dalam menggunakan pelbagai strategi pengajaran yang merentas semua cabang kurikulum bagi membolehkan semua murid belajar dan melibatkan secara aktif dalam kelas. Kemahiran sosial banyak dikaitkan dengan proses pembentukan kendiri individu. Oleh itu, keberhasilan utama pedagogi inklusif yang digunakan iaitu dari segi perkembangan sosial murid mampu memberi kesan yang besar kepada MBK selaras dengan Falsafah Pendidikan Kebangsaan.

\section{Rujukan}

Abdul Rahim Hamdan dan Muhamad Khairul Anuar Hussin. (2013). Persepsi Guru Aliran Perdana Terhadap Inklusif. 2nd International Seminar on Quality and Affordable Education.

Aisyah Abdul Malek dan Mohd Nazri Abdul Rahman. (2019). Pendekatan Bercerita Berasaskan Kurikulum Berkepelbagaian Budaya Untuk Pembelajaran Literasi Awal Kanak-Kanak. Jurnal Kurikulum \& Pengajaran Asia Pasifik, 7(3), 28-34

Alper,S., Ryndak. D. L, \& Schloss, C.N. (2001). Alternate assessment of student with disabilities in inclusive settings. Boston: Allyn \& Bacon.

Amir Hasan (2002). Penteorian Sosiologi dan Pendidikan : Edisi Kedua. Tanjung Malim 
Ang, C.T. \& Lee, L.W. (2018). Pendidikan Inklusif. Petaling Jaya: Sasbadi Sdn. Bhd.

Ballard, K. (2012). Inclusion and social justice: teachers as agents of change. In Teaching in Inclusive School Communities, S. Carrington \& J. Macarthur (eds.), 65 - 87. John Wiley \& Sons:Australia.

Bhatnagar, N. \& Das, A. K. (2013). Nearly two decades after the implementation of the Personswith Disabilities Act: Concerns of Indian teachers to implement inclusive education. International Journal of Special Education, 28(2), $104-113$.

Booth, T., Ainscow, M., Black-Hawkins, K., Vaughan, M. \& Shaw, L. (2000) The Index For Inclusion: Developing Learning And Participation In Schools. (Bristol, CSIE).

Cajkler, W., \& Addelman, R. (2000). The practice of foreign language teaching (2nd ed.).London: David Fulton Publishers.

Dynak, J., Whitten, E. \& Dynak, D. (1997). Refining the general education student. Teaching Education Collaboration 19(1):64-74. Education 21 (3): 36-44.

Eaton, K., Salmon, S., \& Wischnowski, M. (2004). Evaluating co-teaching as a means for successful inclusion of students with disabilities in a rural district. Rural Special Education Quarterly,(23), 3-14.

Edmunds, A. (1998). Classroom teachers are not prepared for the inclusive classroom. Exceptionally Education Canada 8(2):27-40.

Efendi Zakaria (1998). “Pembelajaran Koperatif”. Bangi: Universiti Kebangsaan Malaysia.

Efi Paparistodemou, Despina Potari, \& Demetra Pitta-Pantazi (2014). Prospective teachers' attention on geometrical tasks. Educ Stud Math, 86: 1-18.

Elksnin, L.K. \& Elksnin, N. (2006). Teaching Social-Emotional Skills at School and Home. Colorado: Love Publishing.

Florian, L. \& Black - Hawkins, K. (2011). Exploring inclusive pedagogy. British Educational Research Journal, 37(5), 813-828.

Florian, L. \& Spratt, J. (2013). Enacting inclusion. A framework for interrogating inclusive practice. European Journal of Special Needs Education, 28 (2), 119-135

Florian, L. (2014). What counts as evidence of inclusive education? European Journal of Special Needs Education, 29(3), 286 - 294.

Florian, L. \& Kershner, R. (2009). Inclusive pedagogy, in Daniels, H., Lauder, H. \&Porter, J. in Knowledge, Values and Educational Policy: A Critical Perspective. New York: Routledge, 173183.

Florian, L. (2016). Inclusive Pedagogy Moray House School of Education Election Briefings. www.ed.ac.uk/education

Frost, L, \& Bondy, A. (2002). The Picture Exchange Communication System training manual (2nd ed.). Boston: Pyramid Educational Consultants.

Grace, N. M. F., Rosadah Abdul Majid, Mohd Mokhtar Tahar \& Mohd Hanafi Mohd Yasin (2012). Pelaksanaan Amalan Pengajaran Dalam Kelas Inklusif: Adakah Masalah Pembelajaran Pelajar Berkeperluan Khas Ditangani? Seminar International Pasca Siswazah Pendidikan Khas UKMUPSI Siri II 2012. Fakulti Pendidikan, UKM, Bangi. Selangor.

Hart, S., Drummond, M. J. \& McIntyre, D. (2007). Learning without limits: constructing a pedagogy free from determinist beliefs about ability. In L. Florian (Ed.), The Sage Handbook Of Special Education, (pp. 499-514). London: Sage.

Hudson, P. \& Glomb, N. (1997). If it takes two to tango, then why ot teach boot partner to dance? Collaboration instruction of all educators. Journal of a Learning Disabilities 30:442-448.

Johnson, D. (2006). Listening to the views of those involved in the inclusion of pupils with Down's syndrome into mainstream schools. Support for Learning 21(1): 24-29.

Johnstone, C.J. (2009). Contributions And Constraints To The Implementation Of Inclusive Education In Lesotho. International Journal of Disability, Development and Education 56(2).

Linda M. Rhinehart Neas. (2012). Co-teaching and different styles of co-teaching. http://brightubeducation.com/special-ed-inclusion-strategies/4096

Majoko, T. (2005). Specialist teachers' perceptions on the inclusion of children with disabilities mainstream school system in Zimbabwe. B.Ed. Unpublished Masvingo State University.

Masniah dan Maizatul Azmah. (2016). Panduan Pelaksanaan Pedagogi Inklusif. Bahagian Pendidikan Khas, Kementerian Pendidikan Malaysia. 
Mazmi bt Maarof \& Noor Syahira bt Jalaluddin. (2019). The Implementation Of Pedagogical Strategies In Inclusive Education Program For Pupils With Special Needs Among Mainstream Teachers: A Case Study. Jurnal Pendidikan Bitara UPSI, (12), 29-38

Noor Aini Ahmad. (2014). Pengurusan Program Pendidikan Inklusif Bagi Murid Bermasalah Pembelajaran: Kajian Secara Naratif Inkuiri. Management Research Journal ,(3), 38-52

Norliah Mohd Amin dan Mohd Hanafi Mohd Yasin. (2016). Pelaksanaan Program Pendidikan Inklusif Murid Berkeperluan Khas dalam Pelan Pembangunan Pendidikan Malaysia 2013 - 2015. Seminar Antarabangsa Pendidikan Khas Rantau Asia Tenggara Siri Ke-6.

Nurul Ain, Md Nasir \& Abd Manaf. (2019). Amalan Aktiviti Pembelajaran Koperatif Dalam Pengajaran dan Pemudahcaraan (PdPC) Pendidikan Seni Visual Di Sekolah Rendah. Journal of Educational Research and Indigeneous Studies, 2 (1), 1-15.

Ong Sze Chong, Zamri Mahamod \& Mohd Izham Mohd Hamzah. (2017). Meneroka Kaedah Pengajaran Guru Cemerlang Bahasa Melayu Negeri Sarawak: Satu Kajian Kes. Jurnal Pendidikan Bahasa Melayu, 7(1), 93-108.

O' Shea, D. J., Williams, A.L., \& Satter, O.R. (1999). Collaboration Across Special education and general education. Journal of Teacher Education 50(2), 147-157.

Parnabas, Vincent A. and Mahamood, Yahaya .(2013). Tahap keyakinan diri dan pencapaianatlet Bumiputera. Jurnal Pemikiran dan Kepimpinan Melayu, 72-77.

Peder Haug. (2017). Understanding inclusive education: ideals and reality. Scandinavian Journal Of Disability Research, 19( 3), 206-217.

Reinard, J. (2001). Introduction to communication research (3rd ed.). New York: McGraw Hill.

Rohani Abdullah. (2001). Perkembangan Kanak-Kanak: Penilaian Secara Portfolio. Serdang: Universiti Putra Malaysia.

Salimah Alias (2013). Persepsi Guru Terhadap Pembelajaran Kooperatif. Conference: International Conference on Public Policy and Social Science (ICoPS) 2013, UiTM Sabah Malaysia At: Pacific Sutera Harbour, Kota Kinabalu, Malaysia.

Soh, K. C. (2015). Creativity fostering teacher behaviour around the world: Annotations of studies using the CFT Index. Cogent Education, 2, 1-18.

TM Makoelle. (2014). Pedagogy of Inclusion: A Quest for Inclusive Teaching and Learning. Mediterranean Journal of Social Sciences. 5(20) : 1259-1267

Villa, R. A., Thausand, J. S., \& Nevin, A. I. (2004). A guide to co-teaching: practical tips for facilitating student learning. California: Corwin Press.

Webster's New World College Dictionary (elementary ed.). (2000). Englewood Cliffs, NJ: PrenticeHall, Inc.

Yadav, M., Das, A., Sharma, S., \& Tiwari, A. (2015). Understanding teachers' concerns about inclusive education, Asia Pacific Education Review.DO1 10.1007/s12564-015-94056.

Yin, R.K. (1994). "Case Study Research : Design and Methods." 2nd ed. Thousand Oak, Calif: Sage.

Yuen, M.J., Westwood, P. \& Wong, G. (2005). Meeting the needs of students with specific learning difficulties in the mainstream education system: data from primary school teachers in Hong Kong International Journal of Special Education 20(1): 67-76.

Zaharah binti Badri. (2013). Kajian Kes Ke Atas Program Pendidikan Inklusif Di Sekolah Aliran Perdana. Jurnal Pendidikan. 1-14.

Zalika Adam \& Faridah Kassim. (2012). Kemahiran Kerja Berpasukan: Etika dalam Pekerjaan dari Perspektif Islam. (dalam talian) Muat turun 4 Mac 2012, http://irep.iium. edu.my/7989/1/KEMAHIRAN_KERJA_BERPASUKAN.pdf.

Zamri Mahamod. (2014). Inovasi P\&P Dalam Pendidikan Bahasa Melayu. Cetakan Ketiga. Tanjung Malim: Penerbit Universiti Pendidikan Sultan Idris. 